\title{
Territory matters. Production and space in Europe
}

\author{
Cristina Bianchetti ${ }^{1 *}$ and Michele Cerruti But ${ }^{2}$
}

\begin{abstract}
Rather than becoming entangled in the dreadful European crisis, contemporary forms of production could redefine the role of territory. The hypothesis discussed in this paper is that an acute gaze at contemporary spaces of production could describe the territories of a different Europe. The paper is divided into three parts. The first, entitled The "grain du monde" metamorphosis, borrows a statement by Boltanski. It aims to emphasize the necessity of focusing our gaze and opening up new research trajectories. The second, entitled Territories and production, presses for an understanding of the relation between production and space in Europe today, apart from the amusing little stories about recycling and crafts. In this part we refer to nine situations we consider emblematic. The last part puts forward a hypothesis aiming to organize new research trajectories. We point out that the various crises that have hit European territories have emphasized the urban outline of production territories. A point of view to confirm which could contribute to making a more cogent, clearer strategy for cities in Europe.
\end{abstract}

Keywords: Europe, Territory, Production

\section{The "grain du monde" metamorphosis}

European territories seem much more complicated today than in the past due to the economic, demographic, ecological, social and institutional crisis of the last twenty years. A recent research project that analyzed some thirty places in Europe helps us express this assertion better (Bianchetti et al. 2015).

The complex processes of redefinition of economies, the change in demographic structure and needs, and immigration act in different ways but converge in their effects on the European territories. While deeply fracturing welfare and asset redistribution policies they produce a fine-grained crumbly territory scarred by many factors not easy to organize. A territory where predicting the needs, wishes and claims of an increasingly uneven population is more and more complicated. Where reduction and growth processes, the complication and centralization of assets, populations, values, rules and rights all

\footnotetext{
*Correspondence: cristina.bianchetti@polito.it

1 Politecnico di Torino, Dipartimento Interateneo di Scienze, Progetto e Politiche del Territorio, Viale Mattioli 39, 10129 Turin, Italy

Full list of author information is available at the end of the article
}

combine. In a way, crisis territories are denser, not less dense than before.

Firstly, this density is given by new types of precariousness, exclusion and erosion. A large part of what, in a long-term process, was deposited on the soil building up fixed-capital has now been consumed, as in any gradual process of physical decay. This is the case of solid spaces such as infrastructures and industrial platforms but also those of the welfare system and social housing. Their strength used to lie not just in their high-quality design but above all in the identity and strength of the social groups they were designed for. The same groups that today seem fragile, suspended and deprived. A provocative, reactionary thinker like Finkielkraut would describe such a remarkable movement of erosion, subsidence and cracking with the expression "consuming the world". The crisis has actually accelerated the consumption of the world, leaving fragments of heritage of which we are unable to thoroughly understand either the nature or entity.

Nevertheless, world consumption is but a step from other processes going in the opposite direction. Take the case of the spreading of heritage capitalization processes. Namely the conflictual or negotiated redefinition of economic, symbolic and relational values. This redefinition 
could actually concern almost everything: material, economic and cultural aspects. Overturning common sense, we might assert that nowadays it is quite rare to find something unsuitable to be capitalized: everything could be intended as patrimony, general wealth, public property, everybody's heritage. It is practices that are being capitalized, before spaces; new heritages are invented; the balance between democratic and oligarchic wealth is being re-written. To ask why we persist so stubbornly in highlighting what has been stolen from us or what we feel we should inherit during this long crisis is almost naïve. This persistence is not only an educational or moralistic stimulus to justify overflowing capitalization. Nor is it only spreading conservatism with very ancient roots.

More than in the past, European territories hold together and overlap increasing and decreasing values; enhancement and weakening; illegal practices and protocols; new functionalism and social animation;the right to housing, nowadays drained by privileges, rights, immunity, and the painful claim to the right to equality by migrants, the poor and those without documents, a value deeply-rooted both in the ideas of laicism and justice as formulated by Enlightenment philosophy, and in the equality principles professed by the Gospels. It is decidedly complicated for our disciplines to recompose so many slivers from contemporary territories within the old metaphors. No nostalgia for past fantasies. Their time is over, run out and expended. The problem is not to restore the symbolic power of growth, wellness and progress, but to challenge the role of our expertise and projects within this different "grain of the world" (Boltanski 2014).

\section{Territories and production}

Observing the different texture of European territories is not an easy task. Let us try to adopt a partial perspective: the relation between territory and production spaces. We will just mention a few situations we consider meaningful for understanding the metamorphosis of this relation. There are nine situations involved in the modification of what we could call the classic types of organization of production during the second half of the twentieth century in Europe. The cases are located mostly in Italy and West Europe because they were deeply studied in past researches and for this reason they are better known than others. Regarding the multifaceted relation between production and city there is obviously no ambition to be nor comprehensive neither representative. The aim of this short essay is mostly moving ideas while opening new research paths.

\section{Great production laboratories}

The development of industry and production in Europe during the second half of the Twentieth century was fundamental in converting territories into large industrial platforms linked with impressive infrastructure development. It involved agglomerations spread over the land, far from the vertical spatial concept typical of many American factories and some European ones at the beginning of the century. An important example in Europe is Limburg, where the 130-km long Albertkanaal connecting Liège and Antwerpis able to transport more than the half Belgium's total production (over 2.7 billion ton- $\mathrm{km}$ in 2010). The canal is the real backbone of a territory full of canals, railways, roads and infrastructure, a widespread form of urbanization and impressive industrialization. Various overlapping waves of industrialization, each based on the previous one, have used infrastructures, soil and subsoil, transforming the orography and the environmental system and causing serious problems soil stability problems. Redesigning each time exclusive, powerful scenarios. Firstly, the coal mines at the beginning of the century, secondly the Ford car industry and, finally, the waste-management specialization of recent years, carried out here for the whole of Belgium. On a territory where water continuously emerges, the settlements sketch out modest, low-density landscapes, and reshoring and growth processes of the industrial sector join this great, new, fragile production platform. It is actually a case of a detailed process, though not very different from the processes of growth-dismantling-regeneration of the last decades of the Twentieth century (Rappaport 2016; Van Acker 2012; Scheepvaart 2010; Marin and De Meulder 2015; Marin et al. 2015; Fochi 2016).

The gargantuan friche industrielle of Aubervilliers, the heart of the Plaine Commune, is one of the largest industrial platforms in the whole of Europe. Its development began in the 1870s and was characterized by large chemical industries, to then gradually but profoundly disintegrate in a tragic, progressive dismantling process. This is the good side of reconversion, which transforms abandoned places into new infrastructure, both economic and political/institutional. At the beginning of the Nineties, the municipalities involved created a "communautéd'agglomération" called Plaine Commune to recover Aubervilliers. When the Métropole du Grand Paris acknowledged its importance it converted the Plaine Commune into an établissement public territorial for 440,000 inhabitants. With a "new industry" as backbone: namely devoted to the audiovisual, press, textile and crafts, health, logistics and media sectors. Abandonment and reconversion have constituted an articulate system of parts and segments that are no longer exclusive fragments. What changes is the scale of the territory/production relation. Exactly like the types of activity, which have a different dimension and duration that is not linear. Is Aubervillers still a productive city? (Setti 2014, 2015; Cerruti But 2015; Gravari-Barbas and Jacquot 2016) 
Rotterdam is the largest port in Europe and was the largest in the world from 1962 to $2004\left(105 \mathrm{~km}^{2}, 466.4\right.$ billion ton-km in 2015). Just like a big city, this enormous port area followed a varying sequence of development, transition, demolition, growth, dismantling and regeneration. Today, complex projects are redesigning the space in a mixité dimension, replacing the large industrial platforms with a complex system of infrastructures, housing, research institutes, academies, wholesalers and retailers, restaurants and catering. The port has become a city and the whole city has simultaneously become a European industrial cluster and a global hub; the new design of the harbor, in continuity with the past, deals with fragments and seems too meticulous and partial compared with the nature of the transformations, but the project is framed in a larger structural skeleton that defines the whole platform as an integrated model. All in all, it is quite a traditional approach (Port of Rotterdam Authority 2014, 2016; Broekman 2016; IABR 2016).

It is obvious that in these three extreme cases of Limburg, Aubervilliers and Rotterdam the main effort is to break with uniform machinery by introducing diversity, adopting a somewhat conformist way which optimistically prefers those solutions generally considered today the most innovative and intelligent: ecology, technology, media and waste management. That uniform machinery was the backbone of vast territories which were (and still are) the great laboratories of the European production system. They have to stay that way. They are worth too much. Orthey have been harmed too much. These large productive platforms represent today the last territorial condition where Schumpeter's creative destruction could still emerge. In such a space the incessant industrial innovation mechanism revolutionizes the economic structure from inside destroying the old, outdated one and creating a new one (Schumpeter 1942). According to Schumpeter this is "the essential fact about capitalism". It is not clear if this is good news in times of crisis. In any case, in these immense European production laboratories bottom-up corrosion of the great industrial fixed-capital is unimaginable. What is also unimaginable is reactivation based on creative crafts and associations, which has frequently been seen as a good solution for the issues of the crisis, for instance to solve some situations of residential, multifamily and peripheral fixed-capital. The classic example of Marjetica Potrč's project at Aubervilliers shows its unrepeatable uniqueness. It is a "scandal" in Badiou's terms, because it declares not only the impossibility but also the irrelevance of what is not production in such places.

\section{The factory city}

Turin is considered the most important company city in Italy. A city where the production work of one enterprise alone stimulated the vertiginous growth of the population in the decade from 1970 to 1980 from 700,000 to over one million inhabitants, with consequent hypersaturation of the land and extremely rapid urbanization processes. Today Turin is handling the impressive inheritance of the Fordist city, while needing to break free from that model. The transformation of the territory is no longer productive. It plays with the weak factory spaces with urban policy cycles and bottom-up movements that are formed and disappear, as widespread as they are temporary. It is a case of a great variety of experiences that devise complex value systems both for peripheral postindustrial areas and the center of the city. Everywhere the Fordist framework is crumbling in molecular fragments of capitalization. The production space is breaking up into "the use made of it", through conflicts, claims and transverse rewriting (Bagnasco 1986; Tranfaglia 1999; Magnaghi et al. 1970; Olmo and Bagnasco 2008; Vassallo 2015, 2016a, 2016b; Port of Rotterdam Authority 2016b).

Zingonia was the dream, never completely realized, of the entrepreneur Renzo Zingone: "building the most modern both residential and industrial city" in the most important productive region of the country, Lombardy. This utopia took shape in the middle of the Italian economic boom, on a late Nineteenth century model. The reasons for its rapid failure were administrative obstacles, a high number of subcontractor enterprises and low investments by the inhabitants. Even so, today Zingonia has around 200 production plants, the important Habilita Clinic and the Atalanta football camp. The inhabitants are mostly immigrants, first from the south of Italy, then from Africa. In 2007, before the great crisis, the immigrants were more than half the population and this was already perceived as a serious social problem and cause of conflicts: $90 \%$ of the Piazza Affari towers were inhabited by immigrants; the Athena towers were considered "a den of illegality and rackets". Today this factory city has two complementary faces: Zingonia is "the Scampia of the North" where people live amidst drug trafficking, decay, garbage and prostitution. But it is also a "lab of the future" with cultures, languages and religions "meeting on the same landing". A stage in equilibrium between social conflicts, decay and multi-prized artistic work (ZIF 1965; Della Valle 1967; Airaldi 1981; De Cecco 2001; Sinatti 2008; Craighero 2010; CTRL 2015; Gervasoni 2016).

Metanopoli is a real "company town" located in San Donato Milanese and built by Enrico Mattei during the Fifties. In this area the balance between living and working has generated a territory with really high quality housing for the middle class. A successful initiative in the middle of the Golden Age: most of the housing was built between the second half of the Forties and the end of the Sixties. Nowadays this estate has mostly been alienated: 
tenants bought the large good quality houses they were renting for their main home, but there were also many cases of investment. Frequently young people come back to their parents' homes, renting them for themselves at a lower price for unemployment reasons. In San Donato there are also many important international enterprises (ENI, BMW, LG, Daikin) and this guarantees a dynamic property market, making this income production circuit created by the multinational oil and gas company an almost perfect mechanism (Zucconi 1986; Gellner 1960; Balducci 1977; Guidarini 2003; Bricocoli et al. 2015).

In Turin, Zingonia and San Donato factory space is becoming a heritage for families. Sometimes it is not worth much, does not fulfill contemporary needs or correspond to the values and desires of living today. Some people would like to get rid of it but are unable to. For others it is a heritage that supports home economics and moments of unemployment, or integrates incomes in a period in which la precariété est partout. Then again, it is a refuge for immigrants, a place symbolizing claims to a fundamental right, and the difficulty of European cities and territories to accept it. In any case, the cumbersome heritage of production is crumbling to dust.

\section{The district that is no longer a district}

The Prato "rag" district has radically changed in the last twenty years due to macroeconomic and sectorial transformations: verticalization, chain integration, bankruptcy of small enterprises, higher importance of innovation and experimentation, and a different relation with the territory which now includes the plain of Pistoia, Prato and Florence. Meanwhile, the third largest Chinese community in Europe, established in Prato since the Nineties, has built up a new production model based on ready-towear fashion. In a way very similar to that of the industrial district, they use and rent dismantled buildings in the "Macrolotti" areas of the city, frequently combining illegal homes and factories. Prato has been the subject of many studies, be it from an economic point of view (with the Italian and Chinese contrasting or collaborating in a "double district"), an anthropological perspective (which interprets Prato as a "transition zone") or a sociological standpoint (which studies the Chinese community middle-classing and its effects on the territory). The dynamics of this territory have stratified in a complex system of relations and interaction between the real estate market, trade and commerce, and commercial industrial and agricultural production. The district seems to be involved in a sort of metropolization, where proximity advantages and industrial atmosphere come both from the physical infrastructure and the cultural, media and bureaucratic superstructure of all the Florence plain, which is returning to the center of the stage with vitality
(Dei Ottati 2009, 2013; Ceccagno 2003; IRPET 2013; CerrutiBut 2016).

The Italian ceramic tile industry has its heart in the Sassuolo district, which represents $80 \%$ of total production: $350 \mathrm{~km}^{2}$ of territory dominated by a dozen big enterprises and many subcontractors with a history of staggering growth, internationalization, resizing of national production, conversion into a logistic hub, and a new dock also for foreign enterprises which locate their production here in order to get benefit from economies of scale. It is a success story reflected both in the expansion and regeneration of some parts of the territory and the depletion of others. A weakening and strengthening that defines an uncertain but accurate geography of abandonment. The development of the logistic district in Sassuolo has downgraded all the less attractive spaces to storage and warehouses for big local and foreign enterprises. Sassuolo has resisted the macroeconomic setbacks well by means of an even more territorial and specialized approach involving refined transnational relations (Bursi and Nardin 2008; Mattioli 2014, 2015).

The Biella district has been suffering from a deep crisis since at least the Seventies. The situation worsened in 2008 , when production, number of workers and enterprises halved. However, the textile district has recently recovered a positive trend. What has been lost and has remained on the territory is an enormous quantity of abandoned or disused industrial space. In Vallemosso the desolation is boundless: kilometers of desolate factories and a huge quantity of covered, almost always highquality empty spaces which have lost their use value. Most of these spaces are not currently re-usable. Society has reacted with weak initiatives by welfare associations, bottom-up actions and minor projects, hoping for an unlikely massive return of productivity. The production of the industrial district, which has been the backbone of Biella's development, has now become completely detached from the territory generating it (Cerruti But 2014, 2015; Ccia 2016).

According to the purist definition of territorialists, the industrial district is an organization based on productive chorales, close bonds, slow construction and the pulverization of places (Becattini et al. 2009). Where know-how and local cultures matter and workers are not left alone but are the protagonists of a challenge. The society of the district is always protected by the domestic warmth of a community on a territory, whose destiny is to stay put, remain where it is. In these territories interaction is important and the past matters, the long history of the creation of social cohesion and technical development (Becattini 2015). Observed at close range, these territories lightly distort that model: new populations are mixed with the original ones, typological and functional mixité 
decreases, and transnational aspects are well-rooted in metropolitan logics able to offer agglomeration advantages. In the same business history, small or medium productivity is strictly connected to restaurant activities, the money-transfer business, and agricultural sector trade.

\section{Still cities?}

In Europe, the excess of real estate accumulation whether by big groups or families, together with financial capital mobility seeking income, make it quite difficult to imagine growth and wellness levels similar to those of the final decades of the last century. At the same time, both aging and the different composition of populations have already caused (and still will) radical changes in demographic structure and social needs. It is not only a matter of resources but also a deep cultural, social, institutional and territorial transformation. As we mentioned before, we have only considered some slivers of this metamorphosis: situations that are extreme in size, importance and weight of the transformations. One might object that they are not particularly indicative precisely because of their extreme nature. To counter such an objection, we might argue that there is not much research on the territory-production relation so this could be a starting point.

We might begin by saying that these situations are signals of how invincible the power of cities is. All the great production laboratories are rewritten first of all as cities. This redesigningis not just based on the reuse of the vast infrastructure capital, but also on the metaphorical strength of concepts like mixité, density and urbanity. It is also not only a matter of maquillage or policy legitimization. The old-fashioned productive cities are foundering or turning into money-making machines. The industrial districts work within extended urban logics, claiming to be transnational but still pretending to be local. Everywhere the logics of funding, production and capitalization are more intertwined than ever, redefining asymmetries through spaces and productivity hierarchies. Asymmetries in ownership, accessibility, mobility and rights. In other words, the texture of the territory is being rewritten by means of differentials.

The production-city relation has always been dominated by mutual movement oscillating between drawing near and drawing away. Looking at the relations between production and territory we are aware of another abrupt oscillation within the movement. If this hypothesis were verified by the necessary further enquiries, we could make some considerations regarding two aspects we consider both extremely relevant.

The first one concerns the way the new European Urban Agenda is currently being conceived. This issue is again at the center of the debate of our disciplines and a specific reflection about new geographies of production could undoubtedly help. This does not involve a utopic reunification of economy and urbanism as during the age of the foundation of many Research Institutes (the beginning of the 60s). It rather deals with a more precise way of observing the intertwined production dynamics and both social and demographic changes in the territories. Those territories which have been profoundly affected by urbanization processes characterized by different ways, duration and intensities: shrinkage, recycling and heritage assets, which impact on what has layered on the ground. Here a different grain (as Boltanski would say) could be observed. It's a grain made of repeated differentials and asymmetries. In other words, this aspect concerns a strong update both of land and environment management and architecture and urban planning when they have to cope with these territories with a different grain.

The second implication of a research on the relation between city and production probably concerns a different scale: it actually involves our capabilities on reflecting on the continuous process of torsion, destruction and reconstruction of both public and private fixed capital. Which has implications for environmental, residential and infrastructural issues and for ecological footprint or soil consumption. Looking it closer, it pertains to the way we conceive work, rights and duties; the use we make and the functioning of institutions; the meaning of being part of a collectivity. In a way, again, it pertains to the deep change of the grain of European territories. In this sense a research on the relation between city and production could help in glimpsing the outline of another Europe. One not able to offer a dream substituting sustainability, growth and wellness. On the contrary, this Europe is coping with a reform and resetting of the territories after the end of the long growth phase of the twentieth century. While observing this transformation effort it's possible to understand not only our rules and institution corrosion but also the energies that can be employed in the present.

In this sense, the controversial metamorphosis of the territory-production relation does not entail solely a new lexicon and a new set of images.

\section{Authors' contributions}

MCB carried out the research on the case-studies, working with particular relevance on Prato and Biella and participated in designing and drafting the manuscript. CB conceived of the study, supervised the research and participated in its design and coordination and helped to draft the manuscript and revising it. Both authors read and approved the final manuscript.

\section{Author details}

${ }^{1}$ Politecnico di Torino, Dipartimento Interateneo di Scienze, Progetto e Politiche del Territorio, Viale Mattioli 39, 10129 Turin, Italy. ${ }^{2}$ Dipartimento di Culture del progetto, Università luav di Venezia, Tolentini, Santa Croce 191, 30135 Venice, Italy.

\section{Competing interests}

The authors declare that they have no competing interests. 
Received: 6 October 2016 Accepted: 10 November 2016 Published online: 15 November 2016

\section{References}

Airaldi L (1981) Renzo Zingone. Due casi di pianificazione urbanistica privata: il quartiere Zingone di Trezzano sul Naviglio e Zingonia. Storia Urbana 15:91-130

Bagnasco A (1986) Torino. Un profilo sociologico. Einaudi, Torino

Balducci A (1977) II caso Eni a S. Donato milanese. In: Crosta P, Graziosi S (eds) Chi decide la città. Meccanismi e agenti di urbanizzazione nell'area milanese, Clup, Milano, p. 177-208

Becattini G (2015) La coscienza dei luoghi. Il territorio come soggetto corale, Donzelli

Becattini G, Bellandi M, De Propris L (2009) A handbook of industrial districts. Elgar, Cheltenham

Bianchetti C, Cogato Lanza E, Kercuku AE, Sampieri A, Voghera A (eds) (2015) Territories in crisis. Architecture and urbanism facing changes in Europe Jovis, Berlin

Boltanski L (2014) Della critica. Compendio di sociologia dell'emancipazione. Rosenberg and Sellier, Torino

Bricocoli M, Sabatinelli P, Savoldi P (2015) Documento direttore per le politiche dell'abitare a San Donato Milanese. Dastu. Politecnico di Milano, Milano

Broekman M (2016) "The productive city. A new perspective on the making economy of the MRDH". Paper presented at the 2016 Masterclass of the Urbanism Doctorate School of Venice "Reindustrializing Europe", Università IUAV di Venezia 11-12 May 2016

Bursi T, Nardin G (2008) II distretto delle piastrelle di ceramica di Sassuolo tra identità e cambiamento. Franco Angeli, Milano

Ccia BI (2016) Economia biellese 2015. Camera di Commercio di Biella e Vercelli, Biella

Ceccagno A (2003) New Chinese Migrants in Italy. Int Migr 41(3):187-213

Cerruti But M (2014) Oltre la crisi. Biella. Tesi di laure magistrale, Politecnico di Torino, pp 2013-2014

Cerruti But M (2015) “Urban surplus". In: Bianchetti et al. (eds.) Territories in crisis architecture and urbanism facing changes in Europe. Jovis, Berlin. $116-124$

CerrutiBut M (2016) "What's left of Industrial Districts? Rewriting Prato", Paper presented at the 2016 Masterclass of the Urbanism Doctorate School of Venice "Reindustrializing Europe", Università IUAV di Venezia 11-12 May 2016

Craighero A (2010) Viaggio a Zingonia, la «città ideale», tra cumuli di rifiuti e spaccio a cielo aperto. In Corriere della Sera,1 Dec 2010. http://www. corriere.it/cronache/10_dicembre_01/zingonia-citta-ideale_ab80b9dcfd31-11df-a940-00144f02aabc.shtml Accessed 10 Aug. 2016

CTRL (2015) "Zingonia è il futuro". In CTRL magazine. Available at: http://www. ctrlmagazine.it/tag/zingonia-e-il-futuro/ Accessed 10 Aug 2016

De Cecco E (2001), Zingonia: arte, integrazione, multiculture, a + mbookstore, Bergamo

Dei Ottati G (2009) An industrial district facing the challenges of globalization: prato today. Eur Plan Stud 17(12):1817-1835

Dei Ottati G (2013) A transnational fast fashion industrial district: an analysis of the Chinese businesses in Prato. Camb J Econ 38:1247-1274

Della Valle C (1967) "La nascita di una 'città nuova' nella pianura lombarda nord—orientale". Bollettino della Società geografica italiana, VIII/4-6:215-228

Fochi M (2016) Linburg. Territorial Exploration, Tesi di laurea magistrale, Politecnico di Torino, pp 2015-2016
Gellner E (1960) II villaggio sociale dell'Eni. Urbanistica 32:40-57

Gervasoni F (2016) "La vera Scampia? È a Bergamo". In: L'inkiesta, 26 Jan 2016. http://www.linkiesta.it/it/article/2016/01/26/la-vera-scampia-e-a-bergamo/28828/ Accessed 10 Aug 2016

Gravari-Barbas M, Jacquot S (2016) No conflict? Discourses and related in tourism-related tensions in Paris. In: Colomb C, Novy J (eds) Protest and Resistance in the Tourist City. Routledge, New York, pp 31-51

Guidarini S (2003) Metanopoli. Città di Mattei. Abitare 429:139-147

IABR (2016), "Atelier Rotterdam. The Productive City". In International Architecture Biennale of Rotterdam, The Next Economy, Rotterdam 23 April-10 July

IRPET (2013) Prato: il ruolo economico della comunità cinese. IRPET, Firenze Magnaghi A, Perelli A, Sarfatti R, Stevan C (1970) La città fabbrica (contributi per un'analisi di classe del territorio). Clup, Milano

Marin J, De Meulder B (2015) Mapping wasteful urbanization. Re-engineering the resource dependency in Central Limburg. Ecocities in challenging environments. Paper presented at the Ecocity World Summit 2015, Abu Dhabi, 11-13 October 2015

Marin J, Motti M, De Meulder B (2015) Waste(d). Connecting cycles, rethinking infrastructures. Studio Investigations, Department of Architecture KULeuven

Mattioli C (2014) Logistica: fenomeni in atto e scenari di trasformazione nel territorio del distretto ceramico di Sassuolo. Trasp Cult 39:79-84

Mattioli C (2015) Ritorno a Sassuolo. Metamorfosi della produzione e dei territori distrettuali. PhDDissertation, Politecnico di Milano, Milano

Olmo C, Bagnasco A (eds) (2008) Torino 011 Biografia di una città. Mondadori Electa, Milano

Port of Rotterdam authority (2014) Port vision 2030. Progress report 2014. Havenbedrijf Rotterdam N.V Rotterdam

Port of Rotterdam Authority (2016) Port statistics. Havenbedrijf Rotterdam N.V, Rotterdam

Rappaport N (2016) Vertical urban factory. Actar, NY-Barcellona

Scheepvaart De (2010) Statistiek 2010. De Scheepvaart, Hasselt

Schumpeter JA (1942) Capitalism, socialism and democracy. Harper and Brothers, New York

Setti G (2014) Oltre la dismissione. Strategie di intervento architettonico per la modificazione e il consolidamento di trame, tessuti e manufatti industriali. PhD Dissertation, Politecnico di Milano

Setti G (2015) Productive playgrounds. In: Bianchetti et al. (eds) Territories in crisis. Architecture and urbanism facing changes in Europe. Jovis, Berlin. 125-134

Sinatti G (2008), Zingonia:vecchi e nuovi abitanti, vecchie e nuove questioni. Provincia di Bergamo

Tranfaglia N (1999) Storia di Torino. Gli anni della Repubblica, Einaudi, Torino

Van Acker M (2012) From flux to frame, Designing Infrastructure and Shaping Urbanization in Belgium. Leuven University Press, Leuven

Vassallo I (2015) The Fordist city after the factory. In: Bianchetti et al. (eds) Territories in crisis Architecture and urbanism facing changes in Europe. Jovis, Berlin, p 135-145

Vassallo I (2016a) II patrimonio è l'uso che se ne fa. La lezione di Torino, PhD Dissertation, Università luav di Venezia, Venice

Vassallo I (2016b) "Cosa vuol dire patrimonio? E chi decide quali sono i beni comuni?" In: LABSUS. Laboratorio per la sussidiarietà. http://www.labsus. org/2016/05/cosa-vuol-dire-patrimonio-e-chi-decide-quali-sono-i-benicomuni/ Accessed 10 Aug 2016

ZIF (Zingone Iniziative Fondiarie spa) (1965) Zingonia... la nuova città. G. Colombi, Milano

Zucconi G (1986) La città aziendale. Metanopoli nella strategia del gruppo Eni. Storia Urbana 34:211-234 